\title{
ON THE MECHANICAL APPLIANCES EMPLOYED IN THE CONSTRUCTION OF THE MANCHESTER SHIP CANAL.
}

By Mr. E. LEADER WILliaMs, Engtneer in Chief.

Magnitude of Work.-The Manchester Ship Canal, Figs. 1 and 2, Plates 91 and 92, is the largest work of its class in this country; and the Mechanical Appliances used in its construction have been on the largest possible scale, in order to minimise the employment of labour and to hasten the completion of the work. The number of men and boys employed on the Canal has never exceeded 17,000; and about 200 horses have been used. As the excavation amounts to $46 \frac{1}{2}$ million cubic yards, of which over 10 millions are sandstone rock, it is clear that any available number of men and horses would bo insufficient to do the work in any reasonable time. Ninety-seven steam excavators and eight steam dredgers of large power have therefore been employed. The spoil excavated has in most cases had to be taken several miles to the spoil grounds, the position of which has necessarily been selected where land was moderate in price. For this work and for the general purposes of construction 173 locomotives and 6,300 trucks and wagons have been used.

Railway.-A railway of the ordinary $4 \mathrm{ft} .8 \frac{1}{2}$ ins. gauge has been laid along the whole course of the canal, in many places on both sides, with numerous sidings. These lines, with those laid in the bed of the canal for excavating purposes, amount to a length of 228 miles of single line. Flat-bottomed steel rails, 56 lbs. to the yard, with fish joints, are laid on ordinary cross timber sleepers. The cost was about $£ 630$ per mile of single line. The railway and its rolling stock are on a larger scale than some of the passenger and goods lines worked in this country or on the continent. 
Rate of Excavation.-The rate of excavation has varied from $\frac{3}{4}$ million to $1 \frac{1}{4}$ million cubic yards per month. As the work proceeded and the cuttings became deeper and the inclines steeper, and as the sandstone rock required blasting before the excavators could remove it, the rate of excavation in the bottom of the canal is slower. The wagons are hauled out of the bottom of the cuttings by locomotive power, the gradients adopted being generally 1 in 30 . Steam cranes were largely used in rock cuttings, and for setting the masonry. There are employed on the works 124 steam cranes, 192 portable and other steam engines, and 212 steam pumps of various sizes, some being large Cornish pumps that had been brought from the Severn tunnel works. The large plant used consumed about 10,000 tons of coal per month.

Preparation.-As soon as the late Mr. T. A. Walker had got possession of the land as the contractor, he showed great energy in commencing to erect huts, hospitals, and chapels for the workmen; and much honour is due to him and his agents and engineers, not only for the way in which the work has been pushed forward, but also for the care taken for the comfort and welfare of the men. The greater part of the plant was specially constructed for the work; the remainder was principally brought from Mr. Walker's contracts at the Severn Tunnel, and Preston and Barry Dock works. The total cost amounted to $£ 943,610$; the whole plant, huts \&c. are the property of the Ship Canal Company.

Excavators.-The steam excavators are of several types, some being land dredgers working with a chain of buckets; also Ruston and Proctor's steam navvies, and Wilson's and Whitakers' steam excavators, which all work a single large bucket; and Priestman's and other grabs.

Ruston and Proctor's Steam Navvy.-No less than fifty-eight of these steam navvies are used, being the largest number ever employed on any work. The machine, shown in Figs. 3 to 5, Plates 93 and 94, was fully described in Mr. Ruston's paper at the Lincoln Meeting of 
this Institution in 1885 (Proceedings, page 349). Since then the machinery has been improved and strengthened; and it is now a very perfect excavator for almost every description of soil. Its power in removing hard material is greater than that of any other machine yet constructed; soft sandstone rock is removed by it without blasting, powder being required only in hard rock. The buckets for sand excavation on the canal have been increased in size to hold $2 \frac{1}{4}$ cubic yards, Figs. 4 and 5, so that two buckets are sufficient to fill a large earth wagon holding $4 \frac{1}{2}$ cubic yards. The advantage of this excavator being self-propelled is considerable; but its weight is great, and on very soft ground it requires heavy timbers under the rails. It should be put to work if possible with a high feed, 12 to 15 feet, depending on the nature of the soil; and it will clear its own road, and also that required for the line of earth wagons. The cost is about $£ 1,200$. With this machine about 2,000 cubic yards have been excavated in one day of ten hours in good material. A fair average however may be considered to be 600 to 700 cubic yards per day of ten hours. The working expenses of a steam navvy, including wages, may be put at about 308 . per day, or $0.55 d$. per cubic yard excavated. Its disadvantages are that its capability is limited to cutting its way forwards only; and that its great weight has sometimes caused its disuse on the canal works, where the ground has been very soft; no ordinary system of rails and sleepers is sufficient to carry the navvy on very soft ground. The fact that these steam navvies can work in hard material is a great advantage, and they have been used in cuttings where no other excavating machine would work.

Wilson's Excavator.-The Wilson steam excavator, Fig. 6, Plate 95, is of the same type as Ruston and Proctor's. It is made by the firm of Messrs. John H. Wilson and Co., of Liverpool, and has done good work on the canal. It is comparatively light, and is therefore easily moved; it can perform a complete revolution round its centre, and thus can work either way, cut out corners, dress slopes \&c., in a better manner than the ordinary steam navry. Its average work may be taken at 
600 cubic yards per day of ton hours; occasionally it has largely exceeded this quantity when working in favourable soil. The cost is about $£ 1,050$; and the working expenses may be taken at abont $25 s$. per day, or $0.50 d$. per cubic yard excavated.

Whitakers' Excavator.-Another of the jib and bucket type of steam excavator used on the works is constructed by Messrs. Whitaker Brothers, of Horsforth near Leeds. It is similar in most of its details to the Wilson excavator, but its cost does not exceed $£ 800$; the working expenses may be taken at $25 s$. per day, and the average work done at 400 cubic yards per day of ten hours, or $0 \cdot 75 d$. per cubic yard excavated.

Grabs.-The Priestman grab and others have been used principally for excavating foundations and other similar work. In suitable soil it has been found to work up to an average of 300 cubic yards per day of ten hours. The difficulty of getting this class of machine to enter hard or dense ground militates much against its use on large works. Its special advantage consists in its working under water from a higher level.

The Wilson, Whitaker, and Priestman excavators have one great advantage over others. They are reasonably light, and the steam cranes that work them are available for general work when the buckets or grabs are removed.

French and German Land Dredgers. - In addition to the foregoing machines, four excavators, constructed by Messrs. J. Boulet and Co., of Paris, have been employed, Figs. 7 and 8 , Plate 96 ; and three somewhat similar ones made at Lübeck, Fig. 13, Plate 98. On the canal works the three latter are known as the "German" and the four others as the "Frenchman" excavators. These seven machines are of the bucket-ladder kind; they are indeed land dredgers, differing from the floating dredger in the fact that the cutting edge of the buckets when in the act of cutting is always towards the machine, that is, the bucket cuts inwards; whereas in the floating dredger the cutting edge is always turned away from the machine 
at the moment of cutting. As shown in Figs. 10 to 12 , and 14 to 17 , the buckets have no bottom to them, that is, the side next to the chains is left open; and when passing over the top tumbler they discharge their contents upon the shoot below, as shown in Fig. 9, Plate 97.

The first cost of the "Frenchman," Plate 96, is about $£ 2,400$; and under favourable circumstances it is competent to remove a great amount of material. The best day's performances on the different sections of the canal are as follows :-No. 3 section, 1,943 cubic yards ; No. 5 section, 1,624; No. 7 section, 2,250; No. 8 section, 2,025 cubic yards. These are remarkable figures; but the soil and other circumstances must be suitable in order to afford such results. The average day's work on all the districts is about 1,500 cubic yards. If 440 wagons, containing 1,650 cubic yards, were filled per day on No. 8 section by the "Frenchman," it was considered a fair day's work. A bonus of a penny per cubie yard was paid to the men on everything above this quantity. For the excavation of this quantity of material the average daily expenses of the machine in wages of crew, coal, stores, and repairs, the last item being heavy, were about $60 s$., or $0.44 d$. per cubic yard excavated. There were employed upon the excavator an engine-driver and a stoker, and round it a number of men varying from 28 to 43 , the average number being 35 ; the roads required frequent moving. A special locomotive is required in attendance upon the excavator; for though it is traversed by its own power over the train of wagons it is filling, its movement is not sufficiently rapid. The wagons are also kept in motion in the opposite direction by the attendant locomotive.

A great disadvantage in the use of these land dredgers is their necessarily great weight, amounting to at least 80 tons; they consequently entail a heavy and expensive road, which must be maintained if they are to travel at all. They travel on steel rails weighing $80 \mathrm{lbs}$. per yard, carried by cross sleepers spaced about two feet apart. When the ground is at all soft, these cross sleepers are again carried on longitudinals. There is nevertheless a constant danger of the machine upsetting into the cutting, as has actually happened once or twice when working in the light marsh clays. On 
the other hand there is a decided advantage in the fact that the excavator delivers the spoil at a level of 5 or 6 feet above the surface of the ground, instead of merely at that height above the bottom of the cutting, thus saving time and power in haulage up inclines from the cuttings.

It is only in certain materials and under special conditions that economical work can be got out of this excavator. The materials with which it is competent to deal satisfactorily are sand, loam, gravel, or other light soils. In rock however soft it will not work, and hard clays it cannot touch; boulders or imbedded trunks or branches of trees are also found to be insurmountable obstacles. It requires no turning round when it reaches the end of its allotted cutting; it is only necessary to slew the roads, and it cuts its way back to the starting point. It is just as well that this is so, for the taking down of the machine and its re-erection at another site, even though only at the opposite side of the same cutting, is an operation requiring the aid of a large crane, and a considerable gang of men.

German Land Dredger.-The land dredger known as the "German," Plate 98, is made by the Lübecker MaschinenbauGesellschaft, Lübeck. The differences between the German and the Frenchman are slight, and of minor importance, except in one or two particulars. One point of advantage in the German is the wider base given to the machine, enabling the wagons to pass through its centre and receive their load by means of a hopper above, instead of passing at the back and being loaded through a shoot as in the Frenchman. The wider base is of assistance in throwing the centre of gravity farther from the edge of the slope, and therefore in preserving the stability of the excavator. As a matter of fact the author is not aware of any instance in which a German excarator has been tipped into the cutting. Its traversing power is sufficient to move ahead with speed enough to fill the set of wagons standing underneath it, without their having to be moved; hence the attendant locomotive of the French excavator is unnecessary. The best day's performances that are recorded in its favour are as follows:-No. 3 section, 2,073 cubic yards; No. 4 section, 1,736 ; No. 5 section, 1,725 ; and No. 6 section, 
2,400 eubic yards. The average day's work is 1,416 cubic yards, with an average number of $36 \mathrm{men}$. The average daily expenses. of the machine in wages of crew, coal, stores, and repairs, are about 60 s., or $0.50 d$. per cubic yard excavated, which is increased to $1 \cdot 60 d$. per cubic yard by the wages of the labourers who attend on the excavator. The machine weighs about 70 tons, being lighter than the Frenchman, and generally less substantially built; its first cost is the same, namely about $£ 2,400$. In other respects the observations already made in regard to the Frenchman apply equally to the German.

The heavily timbered roads required for working the German and French land-dredging excavators increase the cost of working; and as the first cost of these machines is heary, the cost of excavation does not fall much below the rate of steam navvies, which may be taken in average soils to be $2 d$. per cubic yard, while that of the grabs may be taken at $3 d$., and that of the land-dredging excavators at $1 \frac{1}{2} d$. per cubic yard.

One peculiarity of the excavation has been the employment of a large number of side-tip wagons, capable of holding $4 \frac{1}{2}$ cubic yards each.

Summary of Results.-Summarising the results of experience in the working of land dredgers in England, it may be said that in light material and on level ground they will fill wagons at considerable speed and with economy; and where large excavations of soft material have to be made with rapidity, the bucket-dredging system gives the cheapest and best results. But they will not excavate heavy or strong material ; they are difficult and expensive to maintain, and therefore cause delay to the work; they require a costly and a heavy road, and special precautions on soft ground to prevent them from tilting over into the cutting; and they are expensive to move from one cutting to another.

Floating Dredgers.-The Ship Canal Company also own four powerful steam dredgers. The "Manchester" is a hopper dredger, built by Messrs. W. Simons and Co., of Renfrew, and has double 
screws at each end of the vessel so that it can steam either way, thus avoiding the necessity of turning in the canal. It can dredge 800 tons per hour in favourable material. The "Mersey" and "Irwell" dredgers were built by Messrs. Fleming and Ferguson, of Paisley, in the bed of the canal between Manchester and Warrington. They each dredge 400 tons per hour into hopper barges. The Barry dredger also delivers into hopper barges. There are also working on the canal four other large dredgers hired from Preston, Ayr, Dumbarton, and the Weaver Navigation; besides smaller dredgers, grabs, \&c., worked on barges.

Pile Driving.-At Ellesmere Port there is an embankment faced with stone, one mile long, across an enlargement of the estuary. On each side of the foot of this embankment close timber piling is driven, consisting of pine piles 13 to 14 inches square and 35 feet long. Over 13,000 of these piles have been driven through sand without any trouble, by the use of the water-jet principle. Four steam-pumps were used, which delivered the water at a pressure of about 30 lbs. per square inch through 2-inch india-rubber pipes to the pile, where it was attached to a $1 \frac{1}{2}$-inch wrought-iron pipe which was put down under water-pressure alongside the pile. With this assistance the steam pile-engines quickly drove the pile, which without the disturbance caused by the water-jets in the sand could not be driven. Steam pile-engines are employed on various sections of the work.

Mr. E. Leaden Wirliams said that not one of the machines mentioned in the paper had been invented by himself, and he had therefore no interest in advocating one more than another. The late Mr. Walker, with his great experience in the Severn Tunnel and many other large works, had been an admirable judge of the best class of machinery to use in such a work as the ship canal; and he 
(Mr. E. Leader Williams.)

had been wise enough to see that, with such a variety of soil and so many varying circumstances, the employment of one class of machine alone was hardly the right method to adopt. Therefore while Ruston and Proctor's well-known steam navry was the main tool used, of which as many as fifty-eight were employed, there were also soft cuttings and light alluvial soil and sand to be dealt with, for which Mr. Walker's energy had led him to bring into use the continental machines known as the Lübecker and the Frenchman. Both of these were land dredgers. The Frenchman discharged the material from the top of the machine to the line of railway outside; the Lübecker traversed over the line of wagons and filled them as it went on. Years ago, before he had the honour of being elected a Member of this Institution, he little thought that in days to come he should have to depend so much upon mechanical appliances in carrying out a great work like the ship canal. It was interesting to him as a civil engineer to notice how in the very commencement of any great work of construction, as well as in carrying it out afterwards, it was necessary to have recourse so largely to mechanical engineering. The ship canal, if it had had to depend upon manual labour, would never have been carried out. The mere loss of interest on capital during construction was so great, that everything possible had to be done to push the work forward in the most rapid manner. The difficulties encountered were the very things which it was the engineer's triumph to surmount. Upon this great work every man who had offered himself had been employed; from 16,000 to 17,000 was the largest number ever engaged, but more could have been employed if they had been fortheoming. Therefore it could not be said in this case that the employment of such a great quantity of machinery had in any way interfered with labour: in fact, but for the machinery, there would have been no employment of labour, because the work could not have been carried out in any reasonable time.

The President said the author had had a great deal of experience in connection with the late Mr. Walker, and no doubt had taken the best means of getting so large an amount of material 
removed with the greatest expedition and at the least possible cost. He therefore thought it would hardly be necessary to discuss the interesting paper now read, which would constitute in the Institution Proceedings a valuable record of the difficulties there had been to contend with in this great work and how they had been overcome. He proposed a hearty vote of thanks to Mr. Leader Williams for his paper, which would enable the members all the more to enjoy the visit they were about to make to the canal works through his kind invitation. 


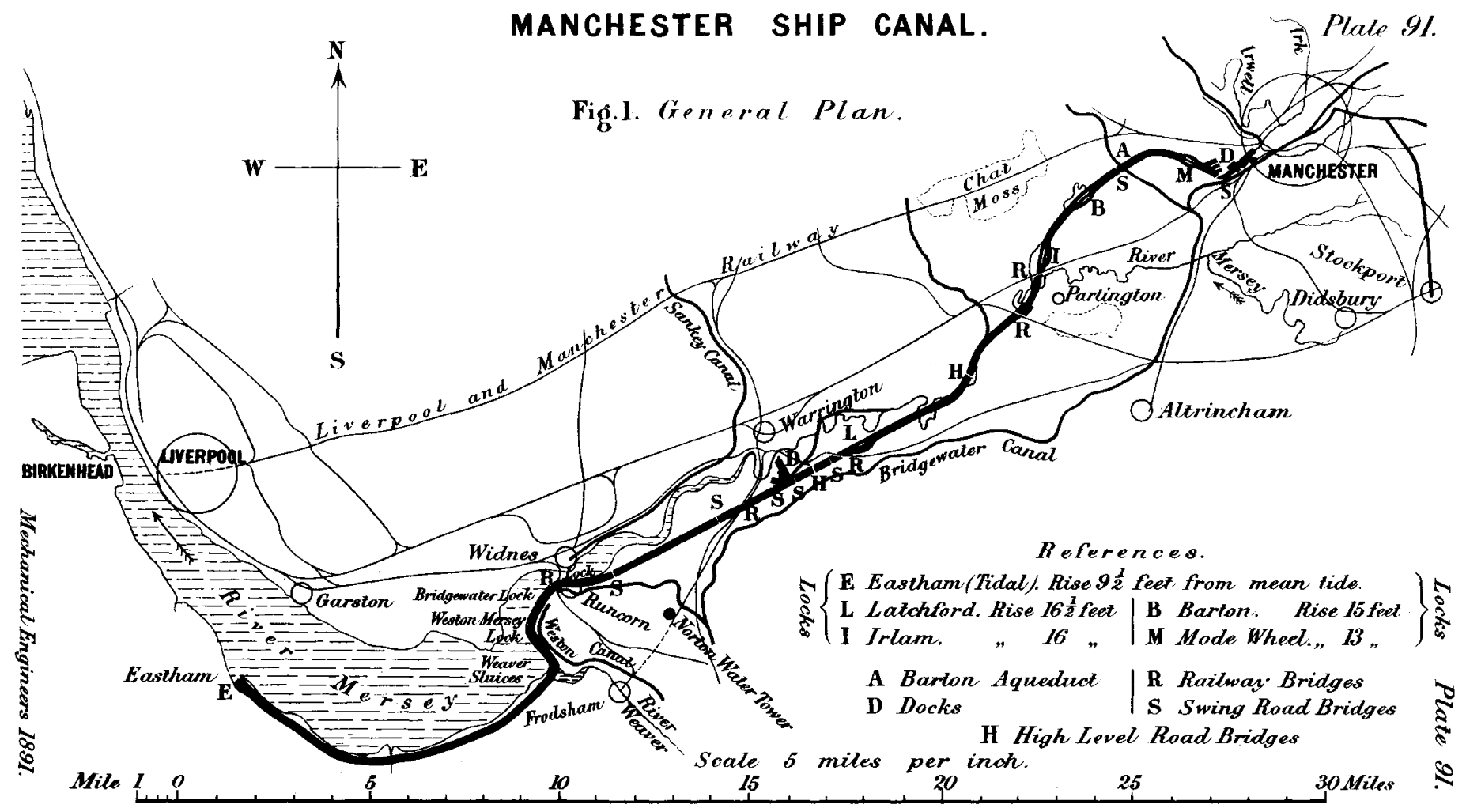


MANCHESTER SHIP CANAL.

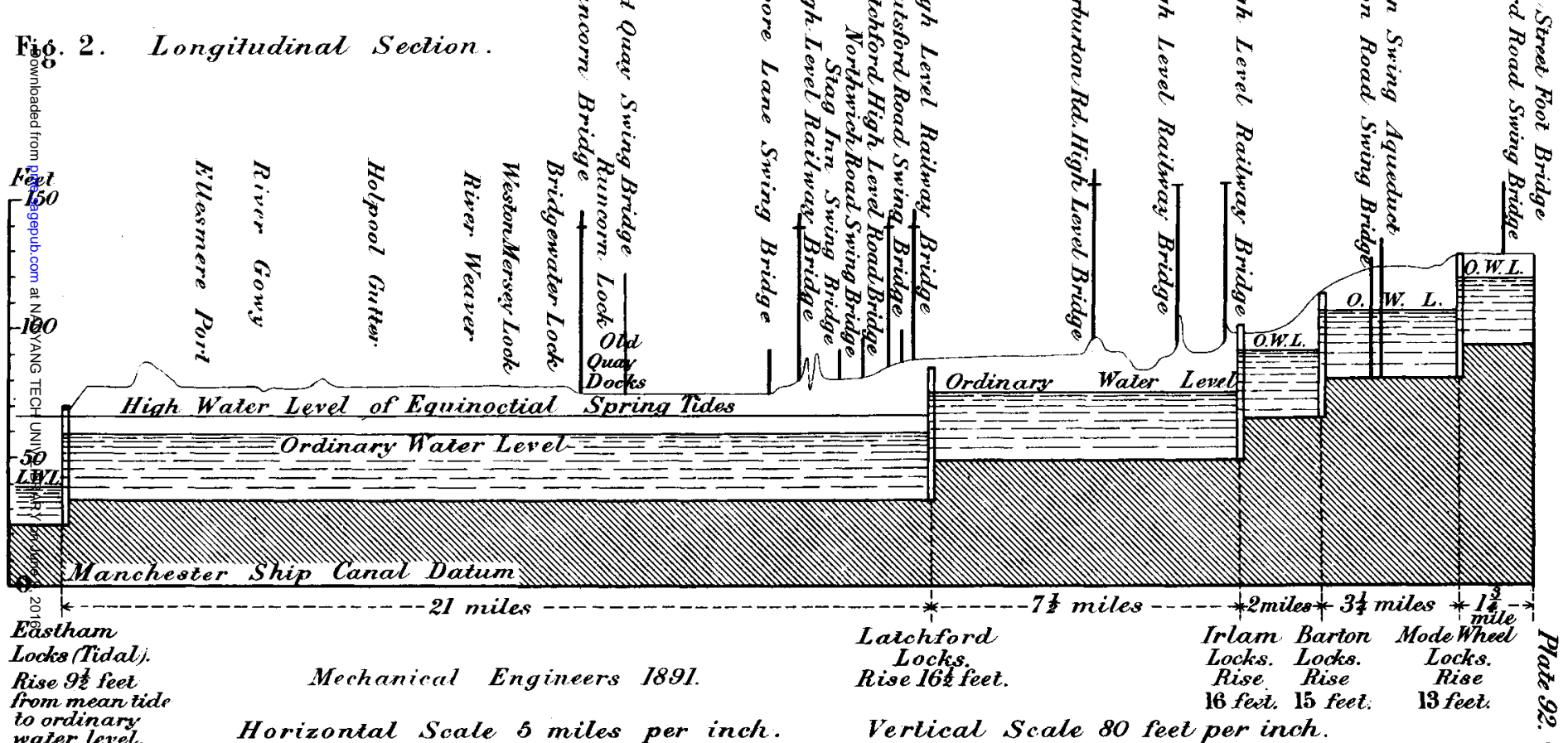

rom mean tid

to ordinary

Horizontal Scale 5 miles per inch.

Verlical Scale 80 feet per inch. Mìles $35 \frac{1}{2}$ 
Fig. 3. Steam Navvy.

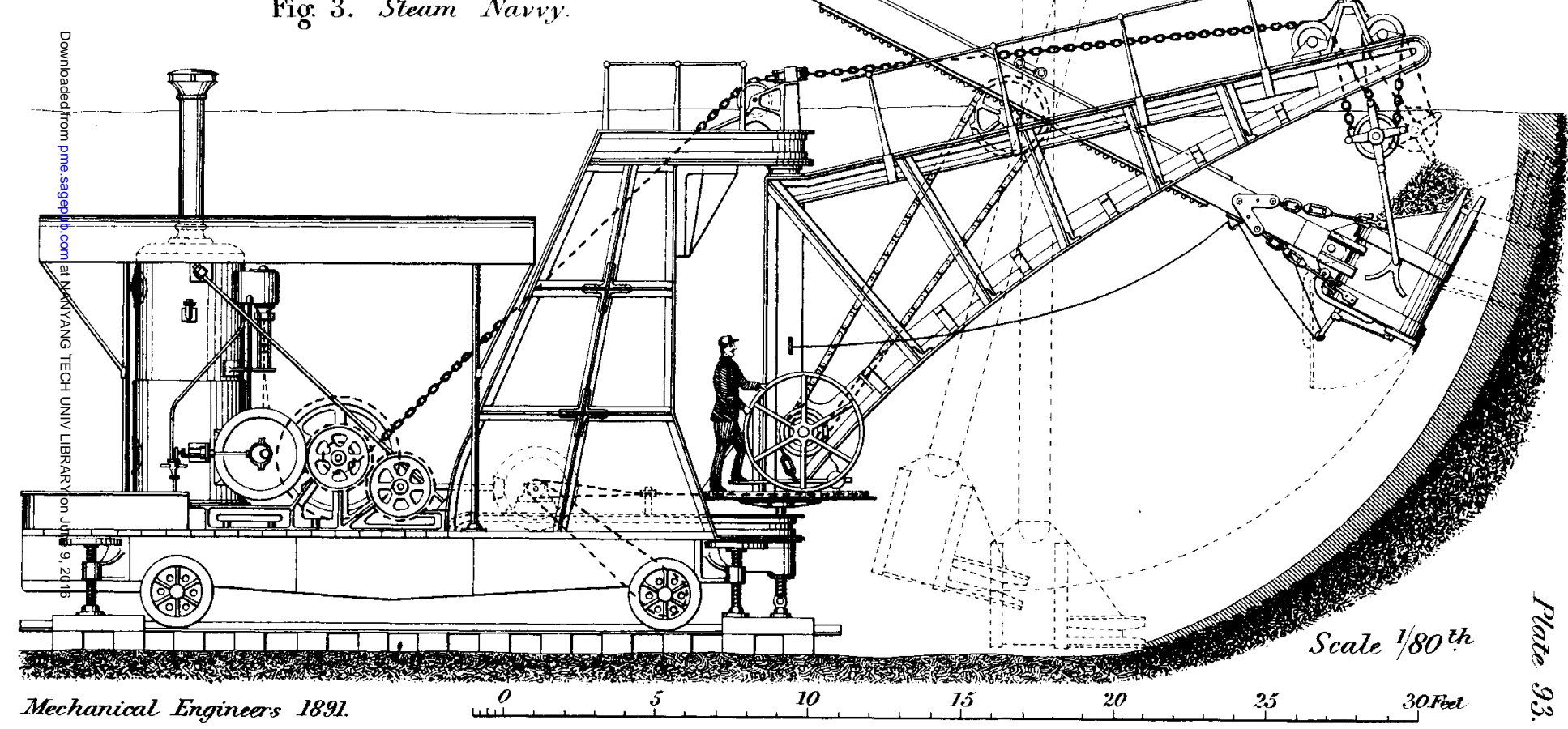




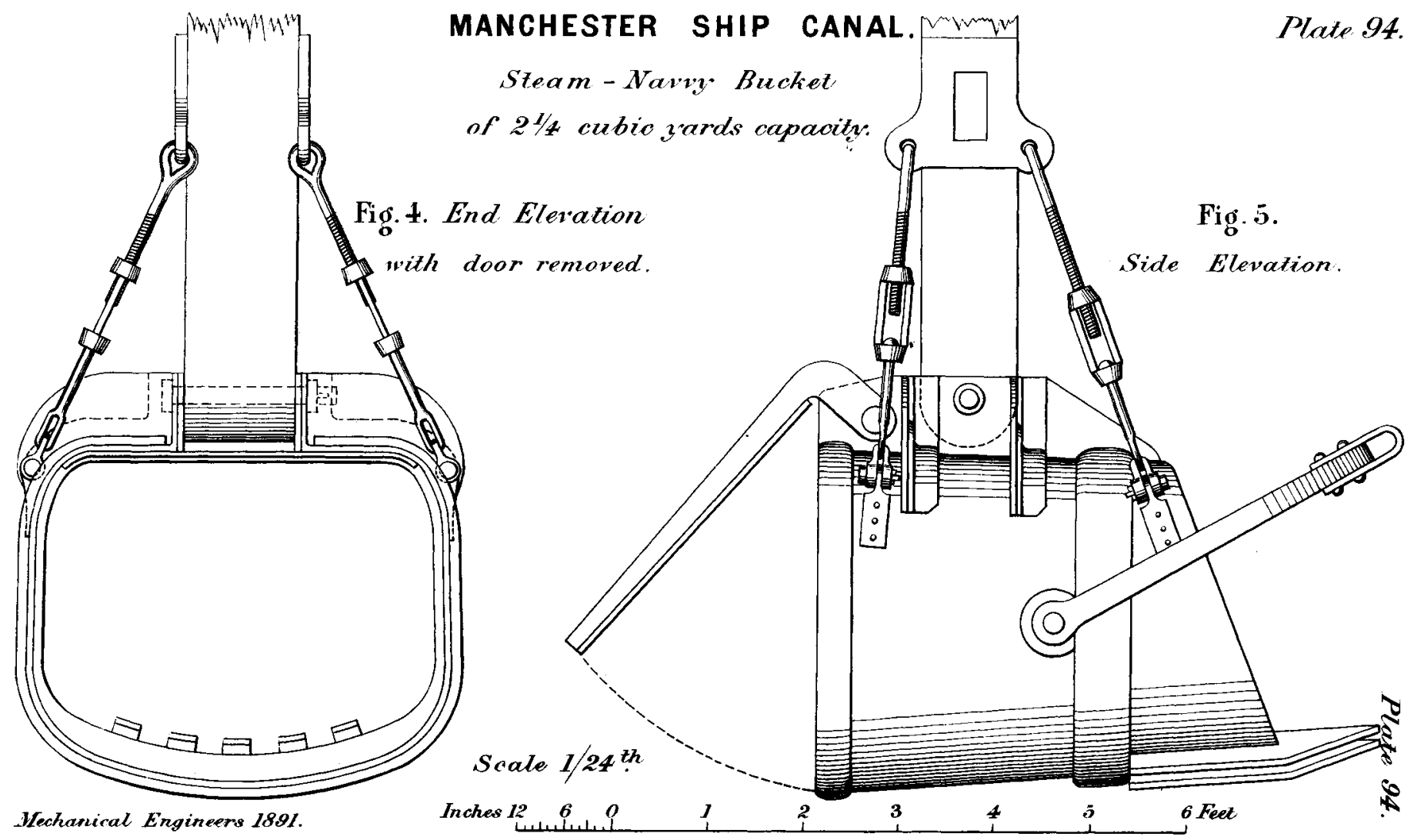

Downloaded from pme.sagepub.com at NANYANG TECH UNIV LIBRARY on June 9, 2016 


\section{MANCHESTER SHIP CANAL. \\ Plate 9.5.}

Fig. 6. Steam Crane Excavator.

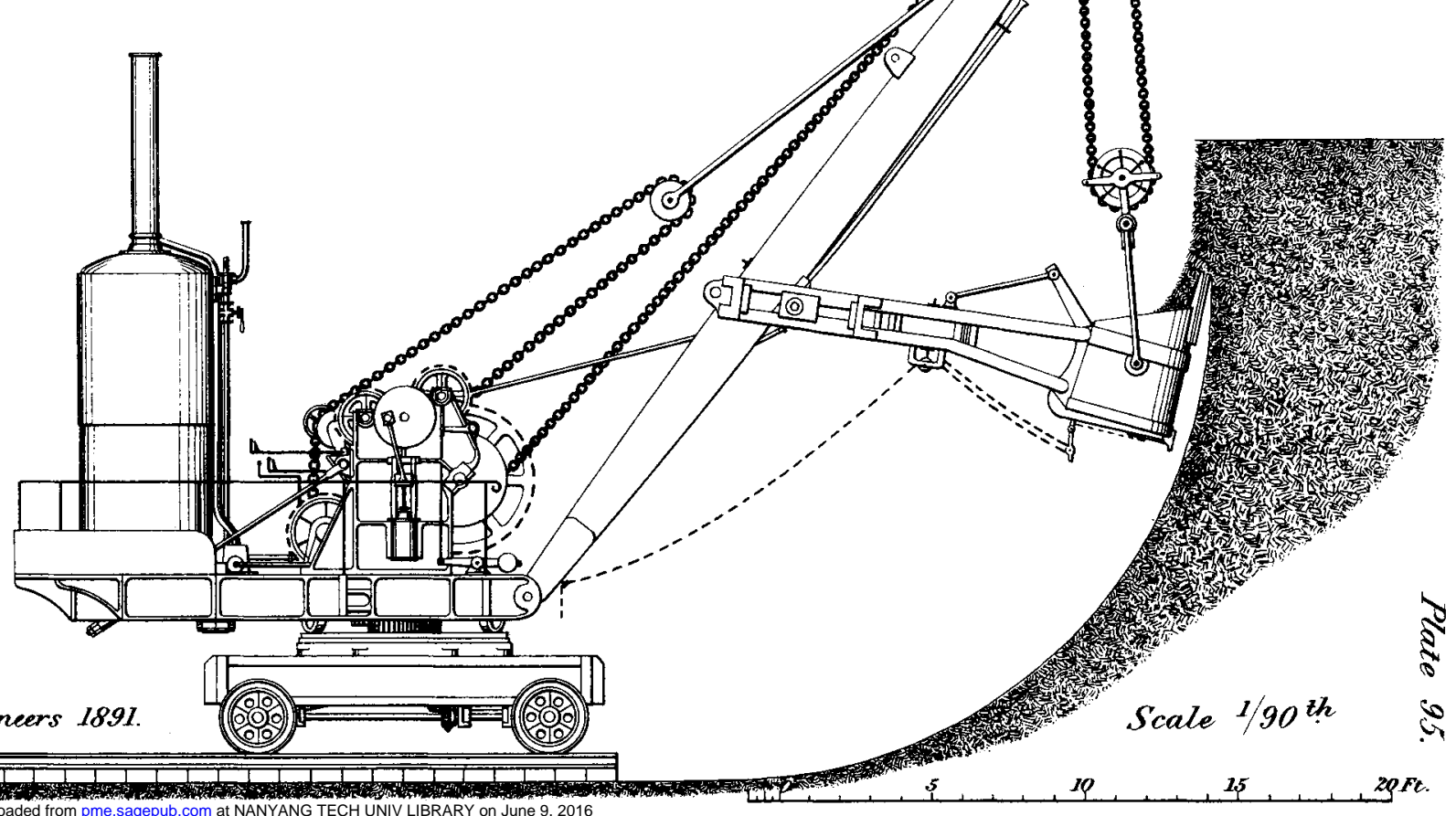

Mechanical Engineers 1891 . 
MANCHESTER SHIP CANAL.

\section{French - Sof Sterm Excuvator.}

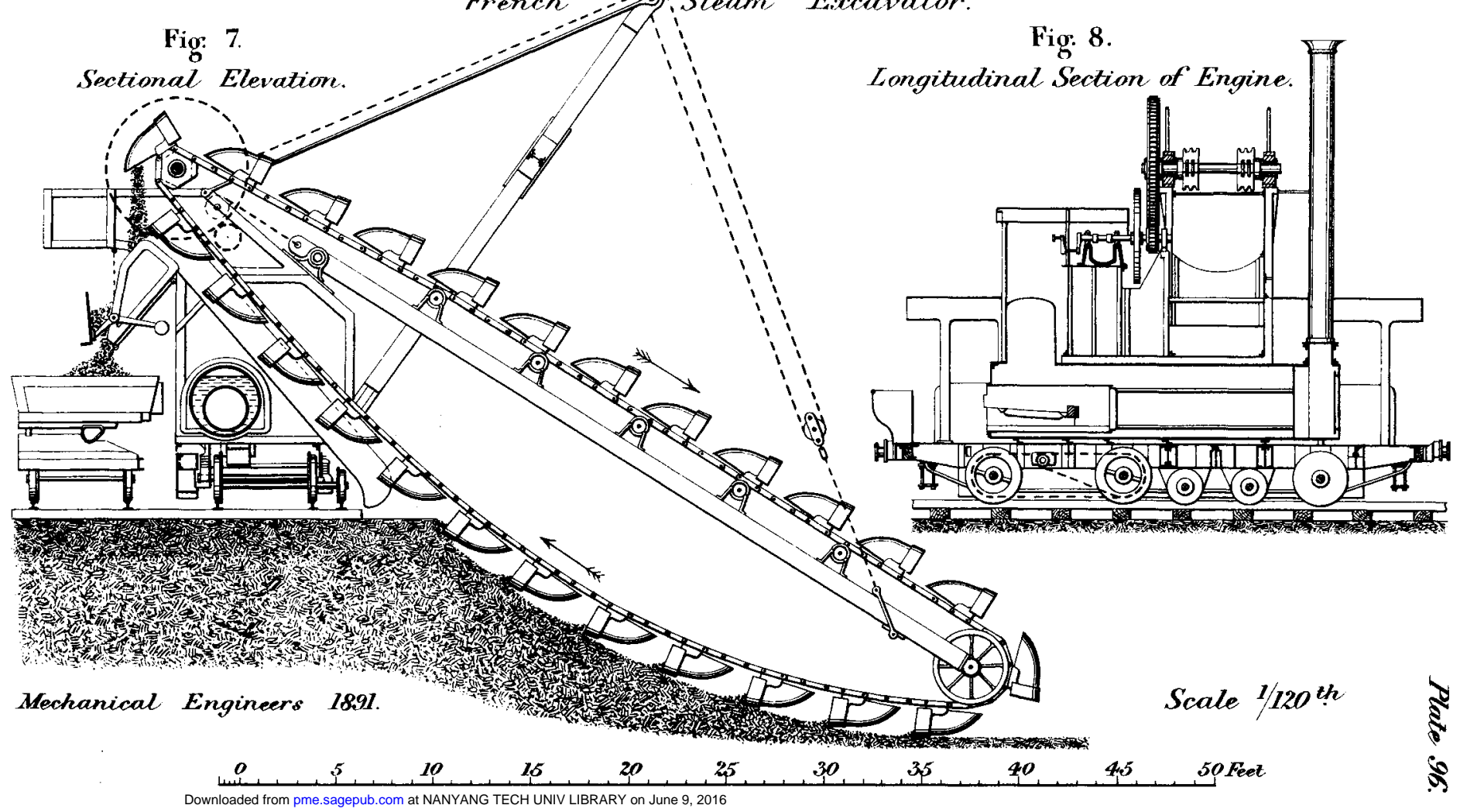




\section{MANCHESTER SHIP CANAL.}

\section{Buckels of French Steam Exoavator: \\ Fig. 9.}

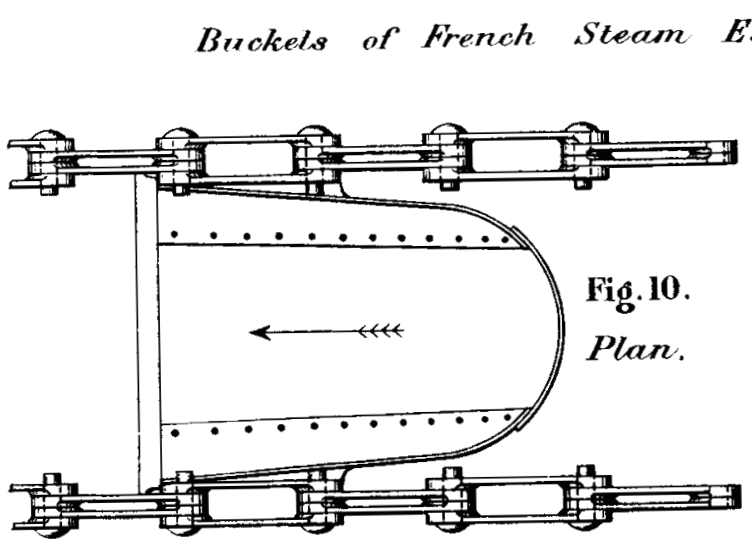

Fig.ll. End Elevation.

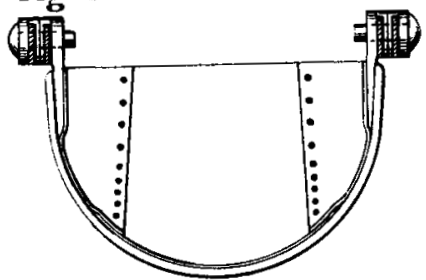

Mechanical Engincers 1891.
Fig.12. Transverse Section.

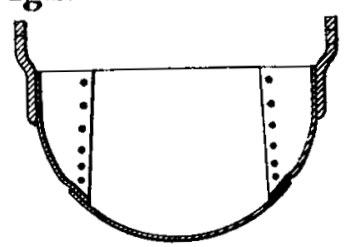

Scale

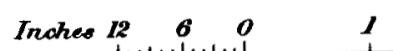

Truches 12

$6 \quad 0$
Tipping of Busket.

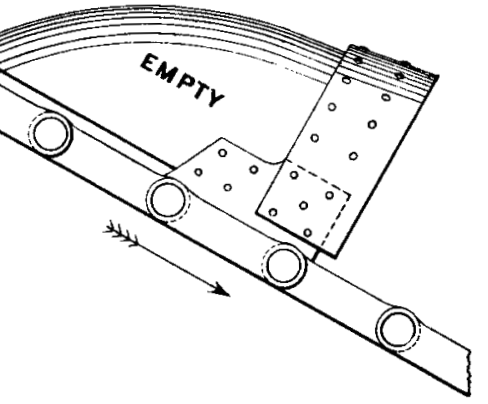




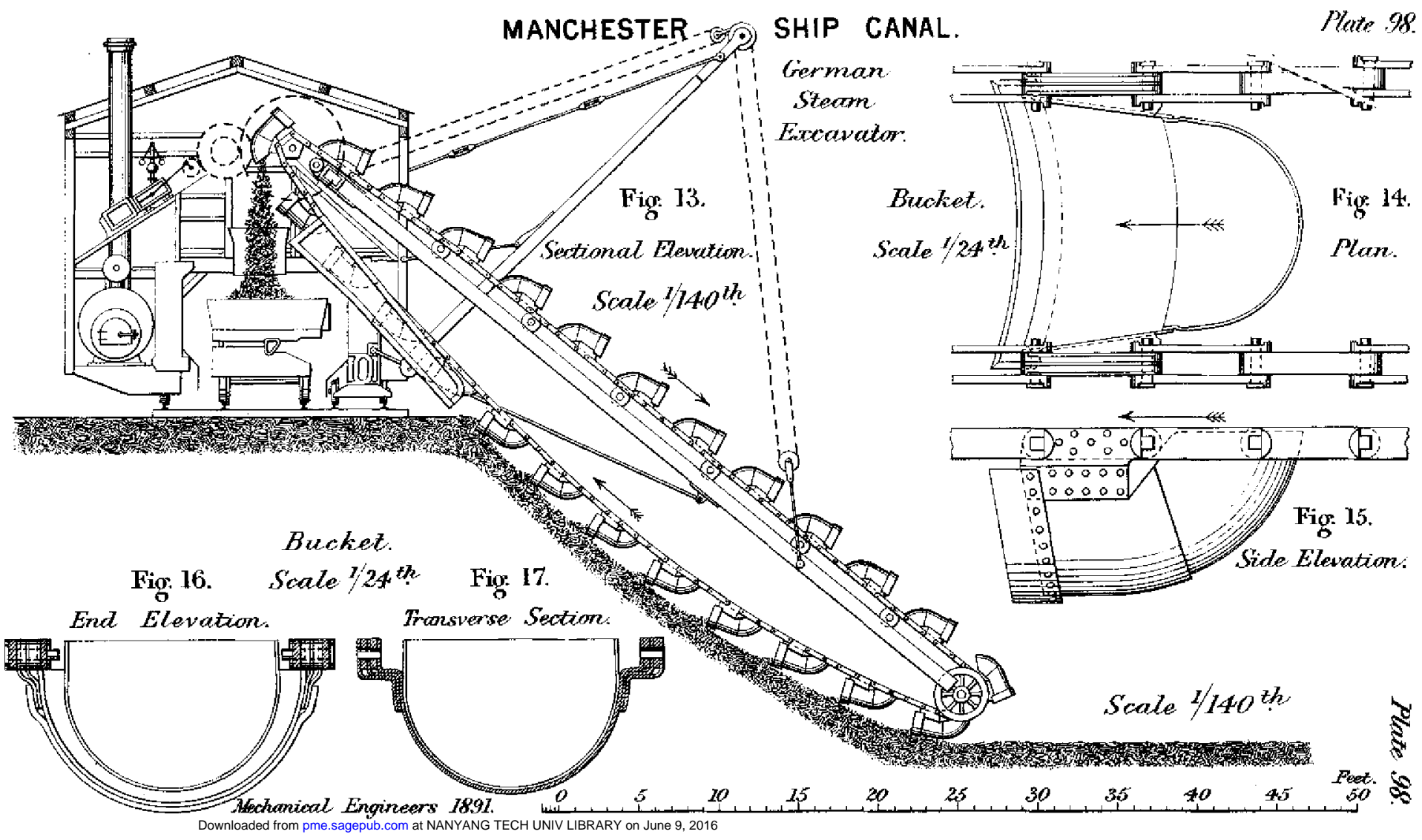

